\title{
PENGARUH TAWAS DAN WAKTU PENGADUKAN TERHADAP KADAR FOSFAT PADA LIMBAH CAIR LAUNDRY DI MARTAPURA KABUPATEN BANJAR
}

\author{
Rifani Alfian, Sulaiman Hamzani, Abdul Khair \\ Poltekkes Kemenkes Banjarmasin Jurusan Kesehatan Lingkungan \\ Jl. H. Mistar Cokrokusumo No. 1A Banjarbaru Kalimantan Selatan 70714 \\ e-mail: rifanialfian47@gmail.com
}

\begin{abstract}
Effect of Stirring Time Alum And Phosphate Levels In Liquid Waste Martapura Laundry In Central District. One of the wastes produced is phosphate. Disposal of waste which contains phosphates in the water can cause eutrophication processes in the aquatic environment. Therefore it needs proper methods for treating waste that contains a lot of laundry phosphate compounds that safely discharged into the environment. This study aims to determine the effect of the use of alum and alum stirring time on levels of phosphate in laundry wastewater XXX in Martapura, Banjar.This type of research is shaped Experimental research. Design The study design is randomized pretest-posttest control group design. The sample was liquid waste from the laundry XXX Laundry washing process that represents the entire population of data analysis using One Way ANOVA Test. The result of a decrease in the average levels of phosphate in sequence on each variation of stirring time, ie 92.7\%; 99.6\%; and 96.7\%. The statistical test used is One Way Anova test. Based on an analysis using One Way ANOVA in the treatment group p-value $(0.00<\alpha 0.05)$, means that there is no effect of stirring time alum against phosphate levels. It is suggested to further researchers to conduct similar research using other types coagulant or coagulants together with other parameters such as BOD, COD, or other.
\end{abstract}

Keywords: Phosphate; liquid waste; alum; stirring time medals.

Abstrak: Pengaruh tawas dan waktu pengadukan terhadap kadar fosfat pada limbah cair laundry di Martapura Kabupaten Banjar. Salah satu limbah yang dihasilkan adalah fosfat. Pembuangan limbah yang banyak mengandung fosfat ke dalam air dapat menyebabkan terjadinya proses eutrophication pada lingkungan air. Oleh karena itu perlu metode yang tepat untuk mengolah limbah laundry yang banyak mengandung senyawa fosfat agar aman dibuang ke lingkungan. Penelitian ini bertujuan untuk mengetahui pengaruh penggunaan tawas dan waktu pengadukan tawas terhadap kadar fosfat pada limbah cair laundry XXX di Martapura, Kabupaten Banjar. Jenis penelitian yang digunakan adalah penelitian yang berbentuk Eksperimental. Desain rancangan penelitian ini adalah The Randomized Pretest-Posttest Control Group Desain. Sampel penelitian ini adalah limbah cair laundry XXX dari hasil proses pencucian Laundry yang mewakili seluruh populasi Analisis data menggunakan Uji One Way Anova. Hasil penurunan rata-rata kadar fosfat secara berurutan pada masing-masing variasi waktu pengadukan, yaitu 92,7\%; 99.6\%; dan 96.7\%. Uji statistik yang digunakan adalah Uji One Way Anova. Berdasarkan analisis dengan menggunakan One Way Anova pada kelompok perlakuan didapatkan nilai $p(0,00<\alpha 0,05)$, dapat diartikan bahwa ada pengaruh waktu pengadukan tawas terhadap kadar fosfat. Disarankan kepada peneliti selanjutnya untuk melakukan penelitian sejenis dengan menggunakan koagulan jenis lain atau koagulan yang sama dengan parameter lain seperti BOD, COD atau logam berat lainnya.

Kata Kunci : Fosfat; limbah cair; tawas; waktu pengadukan.

\section{PENDAHULUAN}

Dengan semakin besarnya laju perkembangan penduduk dan industrialisasi di Indonesia telah mengakibatkan terjadinya penurunan kualitas lingkungan. Padatnya pemukiman dan kondisi sanitasi lingkungan yang buruk serta buangan industri yang langsung dibuang 
ke badan air tanpa proses pengolahan telah menyebabkan pencemaran sungaisungai yang ada dan air tanah dangkal di sebagian besar daerah di Indonesia. Pada industri besar, masalah air limbah mungkin dapat diatasi oleh pihak perusahaan atau industri karena mempunyai modal cukup, tetapi untuk masalah limbah dari industri kecil dan menengah yang jumlahnya sangat banyak sekali tersebut belum tersentuh sama sekali. Sebagai contoh industri kecil laundry yang menghasilkan limbah deterjen[1].

Penelitian terdahulu tentang gambaran deterjen pada air aliran sungai Desa Mekar Kecamatan Martapura Timur, didapatkan hasil konsentrasi surfaktan anionik pada bagian hulu sebesar 2,94 mg/l, pada bagian badan air A sebesar $3,03 \mathrm{mg} / \mathrm{l}$, pada bagian badan air $\mathrm{B}$ sebesar 2,76 mg/l, pada bagian badan air C sebesar 2,63 mg/l, pada bagian badan air D sebesar 2,84 mg/l, dan pada bagian hilir sebesar 2,95 mg/l. Hasil tersebut tidak memenuhi syarat kualitas baku mutu air sungai kelas 1 menurut Peraturan Pemerintah Nomor 82 Tahun 2001 tentang Pengelolaan Kualitas Air dan Pengendalian Pencemaran Air. Untuk kadar surfaktan ionik, kadar maksimal yang diperbolehkan yaitu $0,2 \mathrm{mg} / \mathrm{l}$. Hal tersebut menunjukkan bahwa telah terjadinya penurunan kualitas lingkungan pada air sungai oleh limbah detergen[2].

Di Indonesia khususnya di kotakota besar beberapa tahun terakhir banyak bermunculan usaha pencucian pakaian (laundry) dari yang kecil sampai besar. Dimana banyak masyarakat menggunakan jasa laundry untuk mencuci pakaian mereka karena alasan kemudahan dan kepraktisan. Pada awalnya memang sangat membantu, namun pada akhirnya akan timbul masalah-masalah lingkungan yang disebabkan oleh limbahnya. Salah satu limbah yang dihasilkan adalah fosfat yang terkandung dalam deterjen yang digunakan[3].

Pembuangan limbah yang banyak mengandung fosfat ke dalam air dapat menyebabkan pertumbuhan lumut dan mikroalgae yang berlebihan yang disebut juga dengan eutrophication sehingga air menjadi keruh dan berbau karena pembusukan lumut-lumut yang mati. Pada keadaan eutrotop tanaman dapat menghabiskan oksigen dalam sungai saat malam hari atau bila tanaman tersebut mati dan dalam keadaan sedang mencerna (digest), sedangkan pada siang hari pancaran sinar matahari ke dalam air akan berkurang, sehingga proses fotosintesis yang dapat menghasilkan oksigen juga berkuran[4].

Banyak metode yang telah digunakan dalam proses penurunan kadar fosfat di dalam air, antara lain metode fisika, kimia, dan biologi. Metode yang paling efektif dalam penurunan kadar fosfat adalah metode kimia yakni dengan mengikat senyawa-senyawa fosfat melalui penambahan koagulan, misalnya alum (tawas) dan kapur. Penambahan koagulan bertujuan untuk mempercepat proses pengendapan partikel yang tidak dapat mengendap dalam air dengan metode koagulasi. Salah satu bahan kimia yang digunakan sebagai koagulan adalah tawas atau aluminium sulfat[4].

Penelitian terdahulu tentang Pengaruh Variasi Dosis Tawas Terhadap Penurunan Kadar Fosfat Air Limbah Rumah Sakit PKU Muhammadiyah Surakarta, didapatkan hasil bahwa terdapat pengaruh variasi dosis tawas terhadap penurunan kadar fosfat air limbah Rumah Sakit PKU Muhammadiyah Surakarta yaitu dengan dosis efektif adalah 0,75 gr/l dengan keefektifan $99,8 \%$ [5]. Selain itu penelitian lain menyebutkan bahwa pada proses koagulasi dibutuhkan waktu pengadukan yang relatif cepat yaitu 2-15 menit, sedangkan pada proses pengendapan dibutuhkan waktu lebih lama yaitu 20-40 menit. Maka dari itu penulis ingin mengetahui pengaruh variasi waktu pengadukan tawas terhadap kadar fosfat[1].

Laundry yang diteliti merupakan tempat pencucian pakaian yang berada di kota Martapura, dimana setiap harinya laundry tersebut mengeluarkan air limbah cucian kurang lebih 1500 liter perhari 
dari banyaknya cucian $100 \mathrm{~kg}$ perhari. Dari hasil survei lapangan diketahui bahwa limbah deterjen yang dibuang tanpa melalui proses pengolahan terlebih dahulu, tetapi disalurkan pada sumur khusus penampung air limbah. Kondisi tersebut jelas akan mencemari lingkungan sekitar.

Secara umum tujuan penelitian ini mengetahui Mengetahui pengaruh penggunaan tawas dan waktu pengadukan terhadap kadar fosfat pada limbah cair laundry XXX di Martapura, Kabupaten Banjar. Dengan Mengetahui kadar fosfat awal sebelum perlakuan tanpa pengadukan dan pemberian tawas, Mengetahui kadar fosfat setelah perlakuan dengan variasi waktu pengadukan dan pemberian tawas, dan waktu pengadukan optimal terhadap kadar fosfat pada air limbah laundry di Martapura, Kabupaten Banjar.

\section{BAHAN DAN CARA PENELITIAN}

Desain rancangan penelitian ini adalah The Randomized Pretest-Posttest Control Group Desain, merupakan rancangan paling efektif dalam menunjukkan hubungan sebab akibat. Rancangan ini tidak hanya melengkapi kelompok kontrol maupun pengukuran perubahan, tetapi juga menyertakan tes awal untuk menilai perbedaan antara dua kelompok. Berdasarkan Penelitian sebelumnya, dengan dosis tawas yang ditambahkan yaitu $0,25,0,5$, dan $0,75 \mathrm{~g}$ diperoleh hasil dosis optimum yaitu pada dosis tawas $0,75 \mathrm{~g}$ dengan perlakuan yang sama yaitu waktu pengadukan 10 menit dan waktu pengendapan 20 menit[5]. Rancangan penelitian yang dilakukan pada penelitian sebelumnya dengan mengambil dosis optimum yaitu $0,75 \mathrm{~g}$, kemudian melakukan pengadukan lambat $10 \mathrm{rpm}$ dengan variasi waktu 5, 10, dan 15 menit. Untuk pengadukan cepat ditetapkan $200 \mathrm{rpm}$ dengan waktu 30 detik dan untuk pengendapan ditetapkan waktu 20 menit. Pengujian dilakukan sebanyak 4 kali pengulangan dan setiap perlakuan memerlukan air limbah laundry sebanyak $1000 \mathrm{ml}$, penelitian dilakukan di ruang laboratorium kimia Jurusan Kesehatan Lingkungan.

Populasi dalam penelitian ini adalah seluruh limbah cair hasil proses pencucian laundry yang berada di Laundry XXX di Martapura, Kabupaten Banjar. Sampel penelitian ini adalah limbah cair laundry XXX dari hasil proses pencucian Laundry yang mewakili seluruh populasi. Variabel yang diteliti dalam enelitian ini adalah Aluminium Sulfat (tawas), Limbah Detergen Laundry, Waktu Pengadukan, dan Fosfat.

Data diperoleh dari hasil observasi dan wawancara, pengambilan sampel dilakukan pada pembuangan limbah laundry pada proses pencucian karena sudah mewakili semua limbah laundry tersebut. Pengambilan sampel dilakukan dengan metode grap sampling (sesaat) selama periode tertentu buku-buku dan jurnal penelitian lain yang berhubungan dengan penelitian ini.

Untuk membandingkan variasi waktu pengadukan dan penambahan tawas terhadap kadar fosfat limbah Laundry XXX di kota Martapura Kabupaten Banjar menggunakan uji statistik one way anova menggunakan program komputer.

\section{HASIL PENELITIAN DAN PEMBAHASAN}

Setelah Pengukuran $\mathrm{pH}$, kemudian sampel sebelum perlakuan dimasukkan ke dalam botol sampel. Setelah itu untuk mengetahui pengaruh waktu pengadukan dengan penambahan tawas dilakukan dengan pengadukan menggunakan alat Flocculator melalui dua tahapan kecepatan pengadukan yaitu pengadukan cepat dengan kecepatan $200 \mathrm{rpm}$ selama 30 detik untuk menghomogenkan sampel dengan koagulan. Setelah itu, dilakukan pengadukan lambat dengan kecepatan 10 rpm dengan menggunakan variasi waktu yaitu 5 menit, 10 menit, dan 15 menit untuk proses pembentukan flok dan proses sedimentasi (pengendapan) yaitu selama 20 menit. Dosis koagulan tawas yang dimasukkan sama banyak pada masing-masing perlakuan yaitu $0,75 \mathrm{~g}$ dalam 1 liter air limbah detergen laundry dengan pengulangan sebanyak 4 kali. 
Kemudian sampel yang telah diberi perlakuan disaring dengan kertas saring dan filtrat nya dimasukkan ke dalam botol sampel, selanjutnya dikirim ke Balai Riset Standarisasi Industri Banjarbaru untuk mengukur kadar fosfat pada sampel.
Keadaan air limbah laundry sebelum perlakuan dan Hasil pengukuran kadar fosfat air limbah laundry setelah pengadukan menggunakan tawas (Aluminium Sulfat).

Tabel 1. Keadaan Air Limbah Laundry sebelum perlakuan

\begin{tabular}{rccc}
\hline No & Parameter & Kadar & NAB \\
\hline 1 & Fosfat & $0,412 \mathrm{mg} / \mathrm{l}$ & $0,2 \mathrm{mg} / \mathrm{l}$ \\
2 & $\mathrm{pH}$ & 6,84 & $6,0-9,0$ \\
\hline
\end{tabular}

Tabel 2. Kadar Fosfat Air Limbah Laundry Setelah Perlakuan

\begin{tabular}{cccc}
\hline \multirow{2}{*}{ Pengulangan } & \multicolumn{3}{c}{ Perlakuan } \\
\cline { 2 - 4 } & 5 Menit & $\begin{array}{l}\text { Kadar fosfat }(\mathrm{mg} / \mathrm{l}) \\
\text { 10 Menit }\end{array}$ & 15 Menit \\
\hline 1 & 0,031 & 0,002 & 0,002 \\
2 & 0,039 & 0,001 & 0,017 \\
3 & 0,027 & 0,001 & 0,018 \\
4 & 0,023 & 0,002 & 0,017 \\
\hline Rata-Rata & 0,030 & 0,002 & 0,014 \\
\hline Penurunan Kadar Fosfat & $92,7 \%$ & $99,6 \%$ & $96,7 \%$ \\
(\%) & & & \\
\hline
\end{tabular}

Berdasarkan hasil uji One way anova menunjukkan bahwa terdapat pengaruh waktu pengadukan terhadap kadar fosfat.

Tabel 3. Uji Lanjutan Post Hoc LSD

\begin{tabular}{|c|c|c|c|c|c|c|}
\hline \multirow[t]{3}{*}{ (I) Waktu_pengadukan } & \multirow{3}{*}{$\begin{array}{l}\text { (J) } \\
\text { Waktu_pengadukan }\end{array}$} & \multirow{3}{*}{$\begin{array}{l}\text { Mean } \\
\text { Difference } \\
(\mathrm{I}-\mathrm{J})\end{array}$} & \multirow{3}{*}{$\begin{array}{l}\text { Std. } \\
\text { Error }\end{array}$} & \multirow[t]{3}{*}{ Sig. } & \multicolumn{2}{|c|}{ 95\% Confidence Interval } \\
\hline & & & & & Lower & Upper \\
\hline & & & & & Bound & Bound \\
\hline \multirow{2}{*}{ pengadukan 5 menit } & pengadukan 10 menit & $.029^{*}$ & .004 & .000 & .02 & .04 \\
\hline & pengadukan 15 menit & $.016^{*}$ & .004 & .003 & .01 & .03 \\
\hline \multirow{2}{*}{ pengadukan 10 menit } & pengadukan 5 menit & $-.029^{*}$ & .004 & .000 & -.04 & -.02 \\
\hline & pengadukan 15 menit & $-.012^{*}$ & .004 & .017 & -.02 & .00 \\
\hline \multirow{2}{*}{ pengadukan 15 menit } & pengadukan 5 menit & $-.016^{*}$ & .004 & .003 & -.03 & -.01 \\
\hline & pengadukan 10 menit & $.012^{*}$ & .004 & .017 & .00 & .02 \\
\hline
\end{tabular}

Hasil uji lanjutan Post Hoc LSD diketahui perbedaan antar kelompok yang dirangkum sebagai berikut :

Pengadukan 5 menit - pengadukan 10 menit : signifikan

Pengadukan 5 menit - pengadukan 15 menit : signifikan

Pengadukan 10 menit - pengadukan 15 menit : signifikan
Dengan demikian dapat dikatakan bahwa antar kelompok tersebut memiliki perbedaan yang signifikan.

\section{PEMBAHASAN}

Limbah laundry yang ada di industri di Martapura dapat disebabkan adanya kandungan bahan kimia dengan konsentrasi yang tinggi antara lain fosfat, 
surfaktan, ammonia dan nitrogen serta kadar padatan terlarut, kekeruhan, BOD dan COD tinggi [7]. Dari beberapa referensi bahwa keberadaan fosfat dalam air limbah dapat diturunkan dengan jalan pengendapan secara kimiawi. Senyawa fosfat dapat dihilangkan dengan penambahan koagulan. Adapun faktorfaktor yang harus diperhatikan dalam pemilihan bahan kimia sebagai penghilang fosfat adalah sebagai berikut: 1). Biaya, 2). Efektifitas bahan kimia, 3). Pertimbangan lumpur yang dihasilkan, 4). Kesesuaian dengan proses pengolahan lain, 5). Dosis dan perlengkapan untuk pengadukan dan 6). Efek terhadap lingkungan [4].

Dari beberapa pertimbangan diatas, maka dipilih tawas sebagai bahan koagulan, karena disamping harganya relatif murah, dan mudah didapatkan, tetapi juga aman terhadap lingkungan. Berdasarkan hasil kadar fosfat sebelum perlakuan masih melebihi baku mutu Peraturan Pemerintah Nomor 82 Tahun 2001 tentang Pengelolaan Kualitas Air dan Pengendalian Pencemaran Air batas untuk parameter fosfat sebesar $0,2 \mathrm{mg} / \mathrm{l}$.

Pengolahan yang digunakan oleh peneliti adalah menggunakan tawas dalam bentuk serbuk, diberikan perlakuan pengadukan $10 \mathrm{rpm}$ dengan variasi waktu 5 menit, 10 menit, dan 15 menit dan dilanjutkan proses sedimentasi selama 20 menit dengan menggunakan dosis sebanyak $0,75 \mathrm{gr}$.
Pada proses koagulasi dibutuhkan waktu yang relatif cepat yaitu 2-15 menit, sedangkan pada proses pengendapan dibutuhkan waktu lebih lama yaitu 20-40 menit[1].

Kadar fosfat dari masing-masing pengolahan dengan variasi tersebut telah sesuai dengan Peraturan Pemerintah Nomor 82 Tahun 2001 Pengelolaan Kualitas Air Dan Pengendalian Pencemaran Air batas untuk parameter fosfat sebesar 0,2 mg/l.

Kadar fosfat dengan variasi waktu 5 menit mengalami penurunan sebanyak $92,7 \%$ dengan rata-rata kadar fosfat akhir $0.030 \mathrm{mg} / \mathrm{l}$, kadar fosfat dengan variasi waktu 10 menit mengalami penurunan sebanyak 99,6\% dengan rata-rata kadar fosfat akhir sebesar 0,002 mg/l, dan kadar fosfat dengan variasi 15 menit mengalami penurunan sebanyak $96,7 \%$ dengan ratarata kadar fosfat akhir sebesar 0,014 $\mathrm{mg} / \mathrm{l}$.

Penurunan kadar fosfat terjadi karena proses penggabungan pada saat pengadukan, bergabungnya orthophosphate dengan kation logam dari tawas. Tetapi, kemungkinan yang terjadi pada polyphosphate dan senyawa fosfat organik adalah disebabkan mekanisme absorpsi dan terperangkapnya senyawa tersebut dalam partikel flok yang terbentuk dan mengendap. Ion Aluminium Sulfat (Tawas) bergabung dengan ion fosfat melalui reaksi sebagai berikut[8].

$$
\mathrm{Al}_{2}\left(\mathrm{SO}_{4}\right)_{3} \cdot 14 \mathrm{H}_{2} \mathrm{O}_{(\mathrm{s})}+2 \mathrm{PO}_{4}{ }^{2-}{ }_{(\mathrm{aq})} \longrightarrow 2 \mathrm{AlPO}_{4(\mathrm{~s})}+3 \mathrm{SO}_{4}{ }^{2-}{ }_{(\mathrm{aq})} \downarrow+14 \mathrm{H}_{2} \mathrm{O}_{(\mathrm{s})}
$$

Penurunan ini terjadi karena proses pengendapan partikel-partikel padat dari air limbah dengan gaya gravitasi (9). Pada lingkungan perairan, partikel-partikel padat yang mengendap dalam bentuk $\mathrm{AlPO}_{4}$ tersebut jika berlangsung terus-menerus dan dalam waktu yang lama akan menyebabkan pendangkalan sungai, danau,dan perairan yang lain. Meskipun demikian, efek yang ditimbulkan tidak terlalu buruk dibandingkan jika fosfat tersebut berada di lingkungan perairan dalam bentuk ion fosfat $\left(\mathrm{PO}_{4}{ }^{3-}\right)$ dan terus mengalami peningkatan konsentrasi karena terus menerima buangan dari hasil limbah detergen. Maka hal tersebut akan menimbulkan terjadinya proses eutrifikasi, dimana akan menyebabkan pertumbuhan lumut dan mikro algae yang berlebihan sehingga air menjadi keruh dan berbau karena pembusukan lumutlumut yang mati. Pada keadaan eutrotrof tanaman dapat menghabiskan oksigen dalam sungai saat malam hari atau bila tanaman tersebut mati dan dalam 
keadaan sedang mencerna (digest) sedangkan pada siang hari pancaran pada sinar matahari ke dalam air akan berkurang sehingga proses fotosintesis yang dapat menghasilkan oksigen juga berkurang[4].

Jadi, fosfat yang telah diubah menjadi $\mathrm{AlPO}_{4}$ yang akan mengendap di dasar perairan meskipun dapat menyebabkan pendangkalan sungai, tetapi masih lebih aman dibandingkan dengan ion fosfat $\left(\mathrm{PO}_{4}{ }^{3-}\right)$ jika berada di perairan. Karena $\mathrm{AlPO}_{4}$ yang mengendap atau mengalami proses sedimentasi tidak dapat lagi diserap oleh tumbuhan air sebagai nutrient atau unsur hara, sehingga pertumbuhan tumbuhan air akan berjalan normal dan ekosistem air tidak terganggu karena proses eutrifikasi yang disebabkan oleh limbah fosfat.

Penurunan kadar fosfat dengan variasi waktu 10 menit lebih efektif dibandingkan dengan penurunan kadar fosfat pada variasi waktu 5 menit dan 15 menit. Hal ini mungkin terjadi karena pada variasi waktu 5 menit pembentukan flok belum sempurna atau belum seluruhnya terjadi, masih ada presipitat yang mengandung ion-ion atau zat-zat tertentu yang belum bergabung membentuk flok. Sedangkan pada variasi waktu 15 menit penurunan kadar fosfat lebih kecil dibandingkan dengan penurunan kadar fosfat pada variasi waktu 10 menit, hal ini mungkin disebabkan karena pecahnya sebagian flok yang sudah terbentuk yang akan mempersulit proses sedimentasi. Karena kecepatan pengaruh pengadukan mempengaruhi efisiensi proses pengolahan, kecepatan putaran pengadukan yang terlalu tinggi dapat mengakibatkan pecahnya flok yang sudah terbentuk dan akan mempersulit proses sedimentasi, pada umumnya kecepatan pengadukan berkaitan dengan waktu pengadukan[1]. Hal tersebut menunjukkan bahwa waktu pengadukan juga memiliki pengaruh terhadap proses flokulasi seperti kecepatan pengadukan.

Proses koagulasi dan flokulasi yang optimum banyak dipengaruhi variabel-variabel yang kompleks, seperti kualitas air, kuantitas dan karakteristik air, pengaruh $\mathrm{pH}$, kecepatan pengadukan dan waktu pengadukan, dan temperatur. Untuk kecepatan pengadukan dan waktu pengadukan, kecepatan pengadukan sangat berhubungan dengan proses pencampuran koagulan kedalam air, proses destabilisasi partikel dan perpindahan serta penggabungan presipitat yang terbentuk menjadi flokflok. Waktu pengadukan juga sangat berpengaruh karena berhubungan dengan waktu yang dibutuhkan presipitat saling bertumbukan satu sama lain sehingga cukup untuk membentuk flok dengan kualitas terbaik (10). Disamping itu pada penelitian ini juga memiliki kekurangan yaitu menggunakan koagulan tawas dalam bentuk serbuk (padat) tanpa proses pelarutan terlebih dahulu hal ini juga mungkin berpengaruh terhadap hasil penelitian, karena disebutkan bahwa bentuk koagulan berpengaruh terhadap proses koagulasi - flokulasi, koagulan dalam bentuk larutan lebih efektif dibandingkan koagulan dalam bentuk serbuk atau butiran[4]. Koagulan dalam bentuk serbuk memiliki ukuran partikel atau butiran yang berbeda-beda, ada ukuran butiran koagulan yang lebih kecil dan ada ukuran butiran koagulan yang lebih besar. Untuk koagulan tawas dengan ukuran butiran lebih kecil akan lebih cepat dan lebih mudah larut pada proses pengadukan sehingga mudah bereaksi dengan fosfat dalam limbah cair detergen laundry untuk membentuk flok. Sedangkan untuk koagulan tawas dengan ukuran butiran yang lebih besar sedikit lebih sukar dan lambat larut pada proses pengadukan sehingga dikhawatirkan ada sebagian koagulan tawas yang tidak larut, maka akan menyebabkan tawas yang tidak larut tersebut tidak bereaksi dengan fosfat yang ada pada limbah cair detergen laundry untuk membentuk flok. Hal inilah yang memungkinkan menjadi salah satu faktor pengganggu karena mengurangi efisiensi kerja koagulan tawas yang ditambahkan, karena tidak semua koagulan tawas bereaksi dengan fosfat yang ada pada limbah cair detergen laundry yang sedikitnya mungkin 
menyebabkan perbedaan hasil kadar fosfat pada tiap perlakuan.

Data yang diperoleh menunjukkan bahwa distribusi populasi hasil Uji Normalitas berdistribusi normal, dengan Nilai p (0.864) lebih besar dari $\alpha 0,05$. Sedangkan hasil Uji Homogenitas dapat disimpulkan bahwa semua variasi sama (homogen), dengan Nilai p (0.071) lebih besar dari $\alpha 0,05$.

Selajutnya dilakukan uji One Way Anova menunjukkan bahwa pada waktu pengadukan dengan menggunakan tawas dengan kecepatan 10 rpm dengan berbagai variasi waktu pengadukan yaitu 5 menit, 10 menit, dan 15 menit dengan dosis tawas $0,75 \mathrm{~g}$ didapatkan nilai signifikansi ( $p$-value $\leq 0,00)$, maka Ho ditolak yaitu ada pengaruh penambahan tawas dan waktu pengadukan terhadap penurunan kadar fosfat antara sebelum dan sesudah perlakuan waktu pengadukan dengan penambahan tawas (Aluminium Sulfat) pada air limbah laundry di Martapura Kabupaten Banjar. Kemudian dilakukan Uji Lanjutan Post Hoc LSD untuk melihat perlakuan mana sajakah dari ketiga perlakuan yang berbeda. Maka dari hasil uji Post Hoc LSD dapat dikatakan bahwa antar kelompok tersebut memiliki perbedaan yang signifikan, yaitu antar pengadukan 5 menit dan pengadukan 10 menit, antar pengadukan 10 menit dan 15 menit, serta pengadukan 10 menit dan pengadukan 15 menit.

Dengan demikian dapat diketahui bahwa waktu pengadukan yang paling efektif yaitu 10 menit untuk menurunkan kadar fosfat pada air limbah industri laundry di Martapura Kabupaten Banjar.

\section{KESIMPULAN DAN SARAN}

Kadar fosfat pada air limbah detergen laundry di Martapura Kabupaten Banjar sebelum perlakuan adalah sebesar 0,412 mg/l. Kadar tersebut melebihi nilai ambang batas baku mutu fosfat yang diperbolehkan yaitu $0,2 \mathrm{mg} / \mathrm{l}$. Kadar fosfat rata-rata setelah diberi perlakuan dengan variasi waktu pengadukan dan penambahan tawas, serta adanya proses sedimentasi selama 20 menit, yaitu pada variasi waktu pengadukan 5 menit sebesar $0,030 \mathrm{mg} / \mathrm{l}$ dengan persentase penurunan $92,7 \%$; pada variasi waktu pengadukan 10 menit sebesar $0,002 \mathrm{mg} / \mathrm{l}$ dengan persentase penurunan 99,6\%; dan pada variasi waktu pengadukan 15 menit sebesar $0,014 \mathrm{mg} / \mathrm{l}$ dengan persentase penurunan $96,7 \%$. Ada pengaruh variasi waktu pengadukan terhadap penurunan kadar fosfat air limbah laundry di Martapura Kabupaten Banjar ( $p$-value < $0,00)$. Waktu pengadukan 10 menit dengan pemberian koagulan tawas (Aluminium Sulfat) sudah efektif dalam menurunkan kadar fosfat pada air limbah laundy di Martapura Kabupaten Banjar dengan penurunan rata-rata sebesar $0,002 \mathrm{mg} / \mathrm{l} \quad(99,6 \%)$ sehingga sudah sesuai dengan Peraturan Pemerintah Nomor 82 Tahun 2001 yaitu sebesar 0,2 $\mathrm{mg} / \mathrm{l}$. Berdasarkan hasil penelitian maka dapat dihitung jumlah koagulan yang dibutuhkan untuk mengolah limbah cair detergen laundry di Martapura Kabupaten Banjar, yaitu 0,75 g tawas untuk 1 liter air limbah laundry, berarti dapat disimpulkan bahwa untuk mengolah 1500 l limbah cair detergen laundry setiap harinya dibutuhkan 1,125 g tawas.

Dapat disarankan bagi instansi terkait diharapkan untuk melakukan pengawasan terhadap industri-industri laundry yang berkaitan dengan pengelolaan limbah cair yang dihasilkan dari hasil industri.

\section{KEPUSTAKAAN}

1. Asmadi \& Suharno, 2012. DasarDasar Teknologi Pengolahan Air Limbah. Yogyakarta : Gosyen Publishing

2. Ramadhani, 2014. Gambaran deterjen pada air aliran sungai Desa Mekar Kecamatan Martapura Timur. Karya Tulis Ilmiah. Banjarbaru: Jurusan Analis Kesehatan Politeknik Kesehatan Banjarmasin.

3. Hutomo S, 2015. Keefektifan Dosis Poly Aluminium Chloride (PAC) Dalam Menurunkan Kadar Fosfat Pada Air Limbah Laundry Di Gatak 
Gede, Boyolali. Publikasi Ilmiah. Surakarta: Program Studi Kesehatan Masyarakat Universitas Muhammadiyah Surakarta.

4. Sudi Setyo Budi, 2006. Penurunan Fosfat Dengan Penambahan Kapur (Lime), Tawas, Dan Filtrasi Zeolit Pada Limbah Cair. Tesis Ilmiah. Yogyakarta: Program Pasca Sarjana Universitas Diponegoro Semarang.

5. Zahratul P, 2015. Pengaruh Variasi Dosis Tawas Terhadap Penurunan Kadar Fosfat Air Limbah Rumah Sakit PKU Muhammadiyah Surakarta. Skripsi : Teknik Lingkungan Surakarta.

6. Peraturan Pemerintah Republik Indonesia Nomor 82 Tahun 2001. Tentang Pengelolaan Air Dan Pengendalian Pencemaran Air. Jakarta.

7. Ahmad dan El-Dessouky, dalam rakhmawati dan karnaningroem, 2012. Pengolahan Air Limbah Laundry dengan reaktor biofilter dan koagulasi flokulasi. Prosiding seminar nasional Manajemen Teknologi XVI , E-2-1.

8. Soeparman dan Soeparmin. 2002. Pembuangan Tinja Dan Limbah Cair : Suatu Pengantar. Jakarta: Buku Kedokteran EGC .

9. Sutrisno, Ir C Totok dan Eni Suciastuti. 2007. Teknologi Penyediaan Air Bersih. Jakarta: Rineka Cipta

10. Al-layla dalam rosariawari dan nirwan, 2012. Efektifitas PAC dan Tawas untuk menurunkan Kekeruhan Pada Air Permukaan. 